\title{
Respon Masyarakat Surabaya terhadap Diputuskannya RUU Cipta Kerja Oleh Pemerintah
}

\author{
Taufiqurahman Arsy Ramadhani, Agus Machfud Fauzi \\ Program Studi Sarjana Sosiologi Fakultas Ilmu Sosial dan Hukum, Universitas Negeri Surabaya, Surabaya, Indonesia \\ Correspondence email: taufiqurahman.19034@mhs.unesa.ac.id
}

\begin{abstract}
Abstrak. Artikel ini betujuan untuk menganalisis Respon Masyarakat Indonesia setelah diputuskannya RUU Cipta Kerja yang dibuat oleh DPR. Metode yang digunakan dalam penelitian ini adalah metode penelitian kualitatif desktiptif dengan menjelaskan pandangan sosiologi hukum terhadap dampak yang dihasilkan dari diputuskannya RUU Cipta Kerja menjadi Undang-Undang tetap.Teknik pengumpulan data yang digunakan yaitu dengan mengumpulkan studi pustaka yaitu mengambil dari beberapa sumber seperti jurnal, artikel, berita, majalah ataupun sumber-sumber lain yang berkaitan dengan topik yang sedang dibahas. Hasil dari penelitian ini diharapkan bisa menjadi acuan untuk penelitian-penelitian berikutnya serta dapat memberikan ilmu yang bermanfaat kepada para pembaca.
\end{abstract}

Kata kunci: RUU Cipta Kerja, Omnibuslaw, Pemerintah

Abstract. This article aims to analyze the response of the Indonesian people after the decision on the Job Creation Bill drafted by the DPR. The method used in this research is descriptive qualitative research method by explaining the sociological view of law on the impact resulting from the decision of the Work Creation Bill to become a permanent law. The data collection technique used is to collect literature studies, namely taking from several sources such as journals, articles, news, magazines or other sources related to the topic being discussed. The results of this study are expected to be a reference for future studies and can provide useful knowledge for readers.

Keyword: RUU Cipta Kerja, Omnibuslaw, Government

\section{PENDAHULUAN}

Dikarenakan adanya pengaruh globalisasi secara besar-besaran, pemerintah Indonesia berpikir untuk melakukan perubahan tanggap secara cepat dan tepat. Menanggapi hal tersebut, pemerintah Indonesia atas perintah dari presiden Joko Widodo mengambil langkah yaitu dengan menciptakan Omnibuslaw Cipta Lapangan Kerja. Omnibuslaw Cipta Lapangan Kerja ini diawali dari Visi Presiden Joko Widodo untuk membuka lapangan pekerja yang lebih luas serta dalam jumlah yang sangat besar. Dengan adanya Omnibuslaw Cipta Lapangan Kerja ini, diharapkan Indonesia bisa merubah struktur perekonomiannya yang nantinya akan memberikan dorongan juga terhadap sektor-sektor lainnya agar bisa mendorong tingkat perekonomian yang lebih tinggi. Untuk memenuhi pencapaian tersebut, pemerintah melakukan beberapa hal yaitu:

1. Penciptaan Lapangan Kerja, agar bisa meningkatkan tingkat perekonomian masyarakat, pemerintah membuka lapangan pekerjaan secara besar-besaran agar masyarakat yang pengangguran mendapatkan pekerjaan. Selain itu, pemerintah melakukan pembinaan terhadap masyarakat yang mempunyai tingkat pendidikan rendah melalui program pembinaan yang nantinya program tersebut akan menciptakan para tenaga kerja baru yang berkualitas dan siap untuk melakukan pekerjaannya di berbagai perusahaan-perusahaan besar sehingga mereka mampu bersaing dengan tenaga kerja dari luar negeri yang diakibatkan karena adanya Masyarakat Ekonomi ASEAN (MEA) yang membuat tenaga kerja dari luar negeri dapat dengan mudah masuk ke negara kita.

2. Peningkatan Investasi, dengan diciptakannya Omnibuslaw Cipta Lapangan Kerja menjadikan investor-investor asing dengan mudah nya dapat masuk ke Indonesia dengan syarat-syarat yang sangat simpel dan berisiko. Tujuan pemerintah untuk memberikan izin masuk investor-investor asing dengan mudah yaitu saat investor-investor dari luar negeri menanamkan modalnya di Indonesia, perusahaan-perusahaan tersebut akan membuka lapangan pekerjaan yang nantinya perusahaan tersebut akan mencari tenaga kerja yang ada di Indonesia sehingga tingkat pengangguran yang ada di Indonesia menjadi berkurang serta dapat meningkatkan pendapatan per kapita negara. Selain itu, dengan berkurangnya tingkat pengangguran yang ada di Indonesia, kejadian-kejadian kriminalitas yang terjadi seperti pencurian, perampokan serta pembegalan akan berkurang juga dikarenakan sudah banyak masyarakat yang mempunyai pekerjaan tetap dari perusahaan-perusahaan asing yang menanamkan modal di Indonesia.

3. Peningkatan Produktivitas, dengan adanya pembukaan lapangan kerja secara besar-besaran, diharapkan masyarakat bisa meningkatkan produk-produk yang dihasilkan. Peningkatan tersebut mencakup dari segi kualitas maupun kuantitas, karena semakin tinggi kualitas tenaga kerja maka semakin bagus pula produk-produk yang dihasilkan dan produk yang dihasilkan juga semakin banyak agar tingkat perekonomian negara meningkat secara signifikan. 
Omnibuslaw sendiri adalah metode untuk mengganti atau mencabut suatu ketentuan di dalam Undang-Undang atau mengatur ulang beberapa ketentuan di dalam Undang-Undang ke dalam satu Undang-Undang. Di dalam Omnibuslaw itu sendiri terdapat tiga RUU yang sudah siap untuk disahkan yaitu RUU Cipta Kerja, RUU tentang ketentuan dan fasilitas perpajakan untuk penguatan perekonomian serta RUU tentang pengembangan dan penguatan pada sektor keuangan. Tetapi dari ketiga RUU yang akan disahkan, yang paling menarik perhatian masyarakat Indonesia terutama para kaum pekerja, buruh, petani hingga mahasiswa yaitu pada RUU Cipta Kerja. RUU Cipta Kerja merupakan upaya menciptakan sebuah lapangan kerja melalui kemudahan usaha, perlindungan dan pemberdayaan, usaha mikro, kecil dan menengah, peningkatan ekosistem investasi dan kemudahan berusaha, serta investasi pemerintahan pusat dan percepatan proyek strategis nasional. Berdasarkan pasal 3 RUU Cipta Kerja, telah dikatakan bahwa tujuan dibuatnya RUU Cipta Kerja yaitu untuk menciptakan lapangan pekerjaan yang seluas-luasnya bagi masyarakat Indonesia secara merata. Hal tersebut dilakukan agar seluruh masyarakat Indonesia mendapatkan penghidupan yang layak secara merata. Untuk mewujudkan hal tersebut, ada beberapa poin yang harus dilakukan pemerintah yaitu:

1. Pemberdayaan UMKM serta perkoperasian

2. Kemudahan dalam berwirausaha

3. Peningkatan ekosistem investasi

4. Peningkatan perlindungan dan kesejahteraan pekerja

5. Investasi pemerintahan pusat dan percepatan proyek strategis nasional.

Dengan diciptakannya Omnibuslaw Cipta Kerja oleh pemerintah Indonesia, manfaat yang dapat didapatkan seperti:

1. Menciptakan lapangan pekerjaan yang berkualitas serta kesejahteraan pekerja secara berkelanjutan

Untuk menghadapi Masyarakat Ekonomi ASEAN (MEA) yang menyebabkan munculnya pasar bebas dan mengakibatkan tenaga kerja dari luar negeri bisa masuk dengan bebas ke Indonesia, pemerintah melakukan berbagai upaya untuk menciptakan lapangan kerja yang berkualitas agar masyarakat mampu bersaing dengan para tenaga kerja yang berasal dari luar negeri tersebut. Penciptaan lapangan kerja yang berkualitas ini juga dapat mengurangi angka pengangguran dalam negeri yang termasuk tinggi. Selain lapangan kerja yang berkualitas, para pekerja juga harus selalu diperhatikan kesejahteraannya, karena jika lapangan kerja yang berkualitas tidak didukung oleh Sumber Daya Manusia yang berkualitas juga maka lapangan pekerjaan tersebut akan sia-sia dan rencana pemerintah dalam meningkatkan taraf hidup masyarakat akan gagal.

2. Penyederhanaan regulasi dan perizinan

Dengan adanya Omnibuslaw Cipta Kerja, perizinan dalam mendirikan sebuah perusahaan di Indonesia menjadi lebih sederhana daripada sebelumnya sehingga investor-investor dari luar negeri dapat dengan mudah menanamkan modalnya di Indonesia. Hal tersebut tidak semata-mata untuk menguntungkan investor dari luar negeri saja, tetapi masyarakat juga bisa memanfaatkan hal tersebut untuk mendapatkan sebuah pekerjaan karena semakin banyak investor asing yang menanamkan modal nya di Indonesia maka semakin banyak pula lapangan pekerjaan yang tersedia.

3. Pencapaian investasi yang berkualitas

Penanaman investasi dalam negeri bertujuan untuk meningkatkan pertumbuhan ekonomi secara signifikan. Agar bisa mewujudkan hal tersebut, investasi perlu ditingkatkan agar bisa sejalan dengan kenaikan daya saing Indonesia di mata internasional. Banyaknya investor yang mau menanamkan modalnya di Indonesia juga dipengaruhi oleh poin sebelumnya yaitu kemudahan dalam mengurus perizinan penanaman modal di Indonesia, karena jika perizinan dalam menanamkan modal mudah dan tidak ribet maka investor asing banyak yang menanamkan modal di Indonesia. Selain itu, investasi yang dilakukan oleh investor-investor asing tersebut dapat membuka sebuah lapangan pekerjaan baru yang nantinya masyarakat bisa memanfaatkan kesempatan tersebut untuk memenuhi kebutuhan hidup sehari-hari nya.

4. Pemberdayaan UMKM

Omnibuslaw Cipta Kerja memberikan dampak produktivitas yang lebih tinggi terhadap usaha UMKM. Dengan begitu, pemberdayaan UMKM berjalan sesuai dengan apa yang diharapkan dan mampu bersaing dengan usaha-usaha lainnya. Pemberdayaan yang dimaksud yaitu memberikan bimbingan, pengarahan serta bantuan

kepada UMKM agar mereka juga mampu bersaing dengan usaha-usaha lain pada pasar global.

Tujuan diciptakannya Omnibuslaw ini adalah untuk meningkatkan tingkat perekonomian Indonesia serta meningkatkan pendapatan perkapita dengan cara membuka lapangan pekerja seluas-luasnya agar masyarakat mampu mendapatkan pekerjaan tetap agar bisa memenuhi kebutuhan hidupnya. Dari langkah inilah yang nantinya bisa mengurangi tingkat kriminalitas dan pengangguran di Indonesia agar masyarakat Indonesia mempunyai kehidupan yang aman, tentram dan sejahtera. 


\section{METODE}

Penelitian ini menggunakan metode penelitian kualitatif deskriptif, yaitu menjelaskan secara mendalam dan mendetail mengenai perjalanan Omnibuslaw di Indonesia serta respon masyarakat terhadap disahkan nya RUU Cipta Kerja menjadi Undang-Undang tetap. Metode kualitatif deskriptif dapat diartikan sebagai prosedur pemecahan masalah yang diselidiki dengan menggambarkan atau melukiskan keadaan suatu subyek/obyek penelitian pada saat ini yang didasarkan fakta - fakta yang tampak atau sebagaimana adanya, (Nawawi, 2012:67). Instrument utama dalam penelitian kualitatif yaitu peneliti, oleh karena itu peneliti harus dapat menguasai teori, konsep, materi dan pembahasan apa yang ingin dijadikan sumber data penelitian. Teknik pengumpulan data dalam penelitian ini yaitu teknik studi pustaka dengan mencari sumber-sumber yang berkaitan dengan penelitian seperti artikel, jurnal, buku, dan sumber-sumber online lainnya yang berkaitan dengan respon masyarakat terhadap pengesahan RUU Cipta Kerja di daerah Surabaya. Hasil dari penelitian ini nantinya akan dikaitkan pula dengan analisis dan teori awal dari peneliti sebelum melakukan penelitian dengan mendiskripsikan dan menjabarkan secara detail, mendalam dan menyeluh sesuai dengan tujuan diadakannya penelitian ini yang kemudian diambil kesimpulan dari perolehan data tersebut.

\section{HASIL DAN PEMBAHASAN}

\section{Respon Masyarakat Surabaya Terhadap Pengesahan RUU Cipta Kerja Omnibuslaw Dalam Perspektif Sosiologi Hukum}

Pengesahan RUU Cipta Kerja banyak menjadi sorotan oleh publik dikarenakan isi dari Ruu Cipta Kerja yang dianggap banyak memuat pasal kontroversial. Pasal-pasal kontroversial yang dimaksud antara lain:

1. Pasal 59, yang berisi penghapusan aturan mengenai jangka waktu perjanjian kerja waktu tertentu (PKWT) atau pekerja kontrak.

2. Pasal 79, yang berisikan pemangkasan hari libur yang sebelumnya diatur dalam UU Ketenagakerjaan adalah dua hari diperpendek menjadi satu hari. Selain itu, pasal 79 juga menghapus kewajiban perusahaan memberikan istirahat panjang dua bulan bagi pekerja yang telah bekerja selama enam tahun berturut-turut. Setelah itu, pasal 79 mengatur pemberian cuti tahunan paling sedikit 12 hari kerja setelah pekerja tersebut bekerja selama setahun.

3. Pasal 88, berisikan pengaturan upah kerja yang dimana dalam UU ketenagakerjaan sebelumnya disebutkan 11 kebijakan sebelumnya sekarang menjadi 7 kebijakan saja.

Selain itu, RUU Cipta Kerja dianggap buruh sebagai Undang-Undang yang hanya mementingkan kepentingan investor dibandingkan pekerja-pekerja dalam negeri. Secara substantsi, RUU Cipta Kerja mempunyai dampak yang paling besar pada masyarakat luas terutama kaum buruh dan pekerja dibandingkan RUU lainnya. Maka dari itu serikat buruh dan pekerja dengan didukung oleh seluruh mahasiswa Indonesia melakukan penolakan besar-besaran terhadap diputuskannya RUU Cipta Kerja. Menurut masyarakat, Pemerintah dan DPR dianggap kejar tayang dalam menyelesaikan Omnibuslaw RUU Cipta Kerja ini. RUU ini diharapkan bisa menarik investor-investor asing agar dapat menanamkan modal di Indonesia sehingga dapat meningkatkan tingkat perekonomian masyarakat di masa pandemi COVID-19 seperti ini. Pemerintah dan Badan legislatif DPR RI juga sempat menunda pembahasan RUU Cipta Kerja setelah mendapat perintah dari presiden Jokowi dikarenakan menjawab respon dari tuntutan buruh yang keberatan dengan beberapa pasal di RUU Cipta Kerja. Beberapa pasal yang tertera pada Omnibuslaw RUU Cipta Kerja ini dianggap serikat buruh akan merugikan posisi mereka saat ini. Salah satu yang menjadi sorotan yaitu penghapusan Upah Minimum Kerja yang akan diganti oleh UMP yang dimana UMP ini bisa menyebabkan gaji para pekerja menjadi lebih rendah daripada sebelumnya. Selain itu, para buruh juga mempermasalahkan pasal 79 pada RUU Cipta Kerja yang dimana dalam pasal tersebut menyatakan bahwa istirahat hanya 1 kali seminggu. Hal ini berarti pemerintah memberikan kewajiban kepada pengusaha untuk memberikan waktu istirahat kepada buruh hanya sekali saja sehingga menyebabkan waktu istirahat buruh berkurang. Beberapa ketentuan-ketentuan lainnya juga dianggap kontroversial seperti masalah pekerja kontrak, upah, pesangon, mekanisme PHK serta jaminan sosial.

Setelah disahkannya RUU Cipta Kerja ini, masyarakat terutama kelompok para pekerja, buruh, petani, mahasiswa sampai masyarakat lainnya melakukan penolakan dengan menyuarakan aspirasi mereka di berbagai daerah seperti yang terjadi di Surabaya. Penolakan tersebut berupa demo yang dilakukan oleh masyarakat terhadap RUU Cipta Kerja yang disahkan pada saat itu. Demo ini dilakukan selama 3 hari berturut-turut sampai suara mereka di dengar oleh pemerintah daerah setempat. Penolakan itu tidak hanya semata-mata untuk menolak diciptakannya RUU Cipta Kerja tersebut, tetapi mereka juga memberikan tuntutan-tuntutan seperti tuntutan terhadap Upah Minimum Kerja yang akan diganti oleh UMP, pengurangan uang pesangon, penolakan terhadap adanyaa Perjanjian Kerja Waktu Tertentu (PKWT). Selain itu, para buruh menolak adanya outsorcing seumur hidup, waktu kerja yang dianggap eksploitatif serta hilangnya hak cuti yang dimiliki para pekerja. Perilaku penolakan tersebut termasuk kedalam teori perubahan sosial yang dijelaskan oleh Soerjono Soekanto bahwa perubahan sosial yaitu perubahan pada lembagalembaga kemasyarakatan yang mempengaruhi sistem sosial, nilai-nilai, sikap dan pola perilaku masyarakat. Perubahan yang dimaksud disini adalah sikap masyarakat terhadap pemerintah setelah melakukan pengesahan RUU Cipta Kerja, 
dimana setelah dilakukan pengesahan RUU Cipta Kerja oleh pemerintah masyarakat melakukan penolakan di berbagai daerah di Indonesia. Peristiwa ini menunjukkan sikap masyarakat yang tidak percaya lagi dengan pemerintah karena mereka menganggap bahwa pemerintah sudah tidak bisa dipercaya lagi dalam memimpin sebuah negara. Selain itu, kejadian diatas dapat dijelaskan melalui teori konflik sosial. Teori konflik merupakan kajian mengenai suatu konflik yang terjadi di masyarakat berdasarkan faktor penyebabnya. Teori konflik muncul sebagai respon atas lahirnya sebuah revolusi, demokratisasi dan industrialisasi. Menurut teori konflik, sebuah konflik bisa terjadi dikarenakan faktor internal dan faktor eksternal. Sedangkan dari kejadian diatas, konflik terjadi dikarenakan faktor eksternal yaitu langkah yang diambil oleh pemerintah dalam melakukan pengesahan RUU Cipta Kerja yang dianggap tidak melalui komunikasi dua arah dengan masyarakat tetapi langsung memutuskan sepihak tanpa menerima kritik atau pendapat dari pihak lain.

Dalam menanggapi hal ini, sosiologi hukum sebagai ilmu yang mengkaji tentang hubungan antara hukum dengan perilaku sosial masyarakat menilai bahwa pelaksanaan hukum yang ada di Indonesia dinilai masih kurang terbuka terhadap masyarakat. Terlihat jelas bahwa setelah dimunculkannya Rancangan Undang-Undang Cipta Kerja, masyarakat memberikan respon yang sangat negatif berupa penolakan sehingga masyarakat Indonesia melakukan aksi demo untuk memberikan tututan kepada DPR RI agar RUU Cipta Kerja dibatalkan karena dianggap membuat masyarakat menjnadi makin sengsara. Dalam menghadapi hal ini, DPR RI sebagai perancang Undang-Undang tersebut tidak memberikan respon sama sekali terkait hal tersebut bahkan bersikap acuh terhadap penolakan yang dilakukan oleh masyarakat di luar sana. DPR RI tetap melanjutkan perumusan Rancangan undang-Undang tersebut hingga tahap pengesahan dan diberikan kepada Badan Pemerintah Eksekutif untuk disetujui dan ditanda tangani sebagai Undang-Undang tetap. Selain itu,dapat dilihat dari proses pengesahan RUU Cipta Kerja yang dibahas pada rapat paripurna senin 5 Oktober 2020, dimana pada saat salah satu anggota rapat hendak memberikan kritik atau pendapatnya terhadap Undang-Undang tersebut tetapi mic dari anggota rapat tersebut di mute atau dimatikan sehingga tidak dapat mengutarakan pendapatnya bahkan sampai-sampai anggota rapat tersebut menggunakan mic lainnya tetap saja dimatikan kembali oleh moderator rapat paripurna sehingga anggota rapat tersebut memutuskan untuk walk out dari rapat paripurna tersebut karena merasa tidak diberikan kebebasan untuk berpendapat dan akhirnya memutuskan untuk meninggalkan ruangan rapat. Menurut sosiologi hukum, proses berjalannya hukum yang baik adalah hukum yang telah mencapai keadilan antara hukum dengan negara. Negara yang dimaksud yaitu pemerintah, masyarakat serta beberapa komponen-komponen lainnya. Untuk menciptakan keaadan yang seperti itu, pemerintah harus bersifat transparansi dalam membentuk dan menciptakan suatu aturan karena nantinya hukum tidak semata-mata dibuat untuk kepentingan pribadi atau kelompok saja, tetapi hukum dibuat untuk kepentingan bersama-sama. Jadi alangkah baiknya proses pembentukan sebuah aturan juga melibatkan masyarakat, tidak hanya semata-mata untuk kepentingan sebuah kelompok saja.

Respon perusahaan-perusahaan yang ada di daerah Surabaya setelah terjadinya penolakan yang dilakukan oleh para buruh dan pekerja sepertinya baik-baik saja. Karena setelah kejadian demo besar-besaran yang dilakukan oleh masyarakat termasuk buruh dan pekerja, tidak ada kabar ataupun berita-berita tentang pemutusan hubungan kerja secara besar-besaran ataupun pemberian hukuman pada para buruh dan pekerja yang ada di Surabaya. Perusahaanperusahaan tersebut lebih memilih jalan kooperatif dibandingkan memberikan punishment kepada para pekerja mereka karena mungkin menurut pemilik perusahaan sendiri sudah sepantasnya para pekerja dan buruh melakukan penolakan dan memberikan tuntutan kepada pemerintah karena selain melakukan pekerjaannya, buruh dan pekerja mempunyai tugas lain untuk menuntut serta melakukan penolakan terhadap kebijakan-kebijakan yang dianggap kurang baik dan merugikan masyarakat. Bahkan hingga saat ini pun, suasana perusahaan-perusahaan yang ada di Kota Surabaya tetap kondusif dan baik-baik saja seperti sebelum terjadinya penolakan.

\section{SIMPULAN}

RUU Cipta Kerja yang diciptakan oleh pemerintah sebenarnya mempunyai dampak positif yang banyak daripada dampak negatifnya. Tetapi masyarakat masih kurang terbuka dalam menerima kebijakan tersebut. Pemerintah sebagai lembaga yang memimpin jalannya pemerintah juga seharusnya memberikan arahan serta penjelasan kepada masyarakat mengenai RUU Cipta Kerja tersebut agar masyarakat juga bisa memahami bagaimana maksud dan tujuan pemerintah dalam menciptakan Undang-Undang tersebut serta apa manfaat yang didapatkan setelah melaksanakan apa yang tertera pada Undang-Undang tersebut. Sebagai masyarakat yang baik, kita harus selalu bisa menerima bentuk perubahan yang sedang terjadi di kehidupan kita, karena pemerintah juga tidak mungkin melakukan perubahan untuk masyarakat ke arah yang lebih buruk daripada sebelumnya, kita sebagai masyarakat juga harus bisa open minded dalam menerima suatu perubahan yang ada di dalam kehidupan kita. 
Taufiqurahman Arsy' Ramadhani dan Agus Machfud Fauzi, Respon Masyarakat Surabaya terhadap Diputuskannya RUU Cipta Kerja Oleh Pemerintah

\section{DAFTAR PUSTAKA}

Faqih, Abdullah. "Pasal-Pasal Kontroversial Omnibuslaw Cipta Kerja: Buruh Mogok Kerja Nasional". Selasa, 6 Oktober 2020. https://surabaya.tribunnews.com/2020/10/06/pasal-pasal-kontroversial-omnibus-law-cipta-kerjaburuh-mogok-kerja-nasional?page $=4$. diakses pada tanggal 19 November 2020

Idris, Muhammad. "Jadi Kontroversi, Apa Itu RUU Cipta Kerja?". 05 Oktober 2020. https://money.kompas.com/read/2020/10/05/063213126/jadi-kontroversi-apa-itu-ruu-cipta-kerja?page=all . diakses pada tanggal 19 November 2020

DSLA, Admin. "Omnibus Law Cipta Lapangan Kerja: Pengertian, Tujuan, dan Manfaat". 15 April 2020. https://www.dslalawfirm.com/omnibus-law/ . Diakses pada tanggal 19 November 2020

Amali, Zakki. "Kronologi Omnibus Law Disahkan hingga Jokowi Terima UU Cipta Kerja". 15 Oktober 2020. https://tirto.id/kronologi-omnibus-law-disahkan-hingga-jokowi-terima-uu-cipta-kerja-f5YM . Diakses pada tanggal 20 November 2020

"Perubahan

Sosial".

https://www.studiobelajar.com/perubahansosial/\#: : :text=Menurut\%20Soerjono\%20Soekanto\%2C\%20perubahan\%20sosial,di\%20antara\%20kelompok\% 20di\%20masyarakat. Diakses pada tanggal 20 November 2020. 